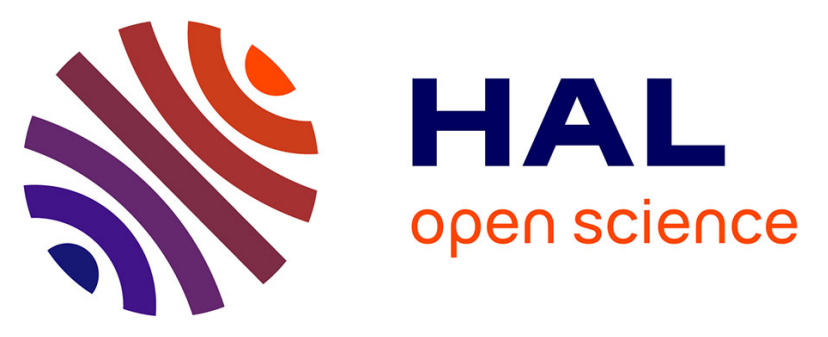

\title{
Soil water storage appears to compensate for climatic aridity at the xeric margin of European tree species distribution
}

Karl H. Mellert, Jonathan Roger Michel Henri Lenoir, Susanne Winter, Christian Kölling, Isabel Dorado-Liñán, Jean-Claude Gégout, Axel Göttlein, Daniel Hornstein, Matthias Jantsch, Nina Juvan, et al.

\section{To cite this version:}

Karl H. Mellert, Jonathan Roger Michel Henri Lenoir, Susanne Winter, Christian Kölling, Isabel Dorado-Liñán, et al.. Soil water storage appears to compensate for climatic aridity at the xeric margin of European tree species distribution. European Journal of Forest Research, 2018, 137 (1), pp.79-92. 10.1007/s10342-017-1092-x . hal-02357326

\section{HAL Id: hal-02357326 \\ https://hal.science/hal-02357326}

Submitted on 24 Nov 2019

HAL is a multi-disciplinary open access archive for the deposit and dissemination of scientific research documents, whether they are published or not. The documents may come from teaching and research institutions in France or abroad, or from public or private research centers.
L'archive ouverte pluridisciplinaire HAL, est destinée au dépôt et à la diffusion de documents scientifiques de niveau recherche, publiés ou non, émanant des établissements d'enseignement et de recherche français ou étrangers, des laboratoires publics ou privés. 
Soil water storage appears to compensate for climatic aridity at the xeric margin of European tree species distribution

\section{Authors}

Mellert, Karl H. (corresponding author, karl.mellert@tum.de) ${ }^{1}$, Lenoir, Jonathan (jonathan.lenoir@u-picardie.fr)², Winter, Susanne (Susanne.Winter@wwf.de) ${ }^{3}$, Kölling, Christian (Christian.Koelling@aelf-rh.bayern.de) ${ }^{4}$, Čarni, Andraž (carni@zrc-sazu.si) ${ }^{5}$, Dorado-Liñán, Isabel (dorado.isabel@inia.es) ${ }^{6}$, Gégout, Jean-Claude (jean-claude.gegout@agroparistech.fr) ${ }^{7}$, Göttlein, Axel (goettlein@forst.tu-muenchen.de) ${ }^{1}$, Hornstein, Daniel (daniel_ho@web.de), Jantsch, Matthias (machja@gmx.de) ${ }^{9}$, Juvan, Nina (nina.juvan@zrc-sazu.si) ${ }^{5}$, Kolb, Eckart (kolb@wzw.tum.de)1, López-Senespleda, Eduardo (elopez@inia.es) ${ }^{6}$, Menzel, Annette (amenzel@wzw.tum.de) ${ }^{10,11}$, Stojanović, Dejan (dejan.stojanovic@uns.ac.rs) ${ }^{12,13}$

Täger, Steffen (steffen.taeger@ aelf-rh.bayern.de) ${ }^{4}$, Tsiripidis, loannis (tsiripid@bio.auth.gr) ${ }^{14}$,

Thomas Wohlgemuth (thomas.wohlgemuth@wsl.ch) ${ }^{15}$, Ewald, Joerg (Joerg.Ewald@hswt.de) ${ }^{8}$,

${ }^{1}$ Forest Nutrition and Water Resources, Technical University of Munich, HansCarl-von-Carlowitz-Platz 2, 85354 Freising, Germany 2UR "Ecologie et dynamique des systèmes anthropisés" (EDYSAN, FRE 3498 CNRS-UPJV), Université de Picardie Jules Verne, 1 Rue des Louvels, FR-80037 Amiens Cedex 1, France ${ }^{3}$ WWF - World Wide Fund for Nature, Reinhardtstr. 18, 10117 Berlin, Germany ${ }^{4}$ AELF Roth, Johann-Strauß-Str. 1, 91154 Roth, Germany ${ }^{5}$ Research Center of the Slovenian Academy of Sciences and Arts, Institute of Biology, Novi trg 2, 1000 Ljubljana, Slovenia and Univerza of Nova Gorica, Vipavska 13, 5000 Nova Gorica, Slovenia ${ }^{6}$ Forest Research Centre, Instituto Nacional de Investigación y Tecnología Agraria y Alimentaria (INIA-CIFOR), Ctra. A Coruña, km 7.5, 28040, Madrid, Spain ${ }^{7}$ LERFoB, AgroParisTech, INRA, F-54000, Nancy, France ${ }^{8}$ Faculty of Forestry, University of Applied Sciences Weihenstephan Triesdorf, D85354 Freising; Hans-Carl-von-Carlowitz-Platz 3, 85354 Freising, Fax +49 816171 4526 
$42{ }^{9}$ Bavarian State Institute of Forestry, Hans-Carl-von-Carlowitz-Platz 1, 85354

43 Freising, Germany

$44{ }^{10}$ Ecoclimatology, Technical University of Munich, Hans-Carl-von-Carlowitz-Platz

$45 \quad 2,85354$ Freising

$46{ }^{11}$ Institute for Advanced Study, Lichtenbergstr. 2a, 85748 Garching

$47 \quad{ }^{12}$ Institute of Lowland Forestry and Environment, University of Novi Sad, Antona

48 Cehova 13d, 21000 Novi Sad, Serbia

$49{ }^{13}$ Faculty of Agriculture, University of Novi Sad, Trg D. Obradovica 8, 21000 Novi

50 Sad, Serbia

$51{ }^{14}$ Department of Botany, School of Biology, Aristotle University of Thessaloniki,

52 GR-54124, Greece

$53{ }^{15}$ Swiss Federal Institute for Forest, Snow and Landscape Research WSL,

54 Zürcherstrasse 111, $\mathrm{CH}-8903$ Birmensdorf

55

56 ORCID (corresponding author): 0000-0002-4263-5763

57

Keywords: climatic aridity, edaphic conditions, European Soil Database, forest ecosystems, macroecology, soil nutrient status

60

Abbreviations: $\mathrm{AWC}=$ available water capacity; $\mathrm{DTOL}=$ tolerances to drought; $\mathrm{EQ}=$ Ellenberg's climate quotient; EQm = modified EQ; ESDB = European soil database; LogEQm = decimal logarithm from EQm; RSC = relative site constancy; $\mathrm{SA}=$ summer aridity; $\mathrm{SDM}=$ species distribution model; $\mathrm{STOL}=$ tolerances to shade; SNS = soil nutrient status

\section{Acknowledgements}

68 This study was funded by the Federal Ministry of Food and Agriculture as well as the Federal Environment Ministry of Germany (project number 28WB4058) and the Bavarian State Forest Administration (project number W42), an authority of the Ministry for Nutrition, Agriculture and Forestry. We acknowledge ICP Forests and the involved country representatives for providing Level-I data. Our thanks also go to Nikolaos Grigoriadis from Greece, Aleksander Marinšek, Alexey Zharov from Germany and Doganay Tolunay from Turkey for data provision. However, the Turkish data could not be used in this analysis, as the ESDB do not contain 
76 soil data from this country. Additionally we are deeply indebted to our

77 colleagues, Solti György, Markus Neumann and Heino Polley for providing us

78 access to the national forest inventories of Hungary, Austria, and Germany,

79 respectively, as well as Monika Konnert (Bavarian Institution for Forest Seeding

80 and Planting) for providing data from provenance plots. Furthermore, we thank

81 all other contributors of vegetation databases and other data sources as well as

82 two anonymous reviewers whose comments helped to clarify important issues. 
84 Abstract

85 Based on macroecological data, we test the hypothesis whether European tree

86 species of temperate and boreal distribution maintain their water and nutrient

87 supply in the more arid southern margin of their distribution range by shifting to

88 more fertile soils with higher water storage than in their humid core distribution

89 range. To answer this question, we gathered a large dataset with more than

90200,000 plots that we related to summer aridity (SA), derived from WorldClim

91 data, as well as soil available water capacity (AWC) and soil nutrient status,

92 derived from the European soil database. The soil compensatory effects on tree

93 species distribution were tested through generalized additive models. The

94 hypothesis of soil compensatory effects on tree species distribution under

95 limiting aridity was supported in terms of statistical significance and plausibility.

96 Compared to a bioclimatic baseline model, inclusion of soil variables

97 systematically improved the models' goodness of fit. However, the relevance

98 measured as the gain in predictive performance was small, with largest

99 improvements for $P$. sylvestris, $Q$. petraea and A. alba. All studied species, except

$100 P$. sylvestris, preferred high AWC under high SA. For F. sylvatica, P. abies and $Q$.

101 robur, the compensatory effect of soil AWC under high SA was even more

102 pronounced on acidic soils. Soil compensatory effects might have decisive

103 implications for tree species redistribution and forest management strategies

104 under anthropogenic climate change. Therefore, soil compensatory effects

105 deserve more intensive investigation, ideally, in studies combining different

106 spatial scales to reduce the uncertainty associated with the precision of soil

107 information.

108 


\section{Introduction}

Contemporary forest management planning increasingly relies on projections from tree species distribution models (SDMs) under future climate conditions (Attorre et al., 2011; Falk and Mellert, 2011; Hlásny et al., 2014; Hanewinkel et al., 2014; Mellert et al., 2015; Zimmermann et al. 2013). SDMs (Guisan and Zimmermann 2000) usually predict the probability of species occurrence or abundance. However, to avoid misspecification (e.g. due to model extrapolations), SDMs should not only be calibrated across the entire species range to ensure that climatic limits are properly covered by the data (Mellert et al., 2011, Beauregard and de Blois 2014), but tree SDMs should also consider soil properties (Thuiller, 2013; Diekmann et al., 2015). As soil data at the location of species occurrence are not available at the continental scale of our study, we tested soil effects in SDMs based on geodata (Panagos et al., 2012).

Soil is a key compartment for forest productivity (Cajander, 1949; Barnes et al., 1982; Bailey 1987). Both water and nutrient availability in soils matter for tree growth (e.g. Mellert and Ewald 2014) and may exert compensatory effects under limiting climatic conditions, especially at the warm and dry edge of their distribution. Yet soil variables are still rarely used in tree SDMs (but see Bertrand et al., 2012; Brus et al. 2011; Coudun et al., 2006; Piedallu et al., 2013; Dolos et al., 2015; Piedallu et al., 2016) and the few studies accounting for soil conditions in SDMs or niche models for trees have all been limited in their spatial extents to countries (Leuschner et al. 2009, Piedallu et al., 2016) or a single biogeographic region(e.g. Dullinger et al. 2012, Nieto-Lugilde et al., 2015). Hitherto, the use of soil variables in tree SDMs of continental extent has been hindered by the lack of soil data at continental to global scales (Ewald and Hédl, 2014). Previous SDMs for plants relied on qualitative soil data (e.g. soil type, Brus et al., 2011; Dolos et al., 2015) as indirect environmental factors in the sense of Austin (1980) or considered only topsoil properties (e.g. Dubuis et al., 2013) which are less relevant for deeper rooting trees than for herbs (Beauregard and Bois, 2014). Therefore, SDMs for tree species should use information from the entire soil profile. 
In a temperate and (sub)mediterranean climate available water capacity (AWC) is an important component of the soil water supply (Blume et al., 2015; Latron et al. 2009). Most importantly, AWC is a crucial buffer that allows trees to survive dry periods (Bréda et al., 2006). This is especially relevant at the rear edge of their distribution. Soil nutrient status (SNS) is an important proxy for nutrient availability (Binkley and Vitousek, 1989). Both factors were mentioned in the formulation of the "relative site constancy" (RSC) hypothesis by Walter (1973). The RSC hypothesis asserts that many plants originating from relatively humid climates prefer moister soils and/or humid microclimates under dryer macroclimatic conditions. Accordingly, higher AWC in the soils should compensate for a more arid macroclimate while higher soil nutrient availability in the soils is expected to improve water use efficiency (e.g. Bradbury and Malcolm, 1977). Thus, the RSC hypothesis predicts a shift of the probability of occurrence of temperate trees towards soils with high AWC under high summer aridity (SA). We further assume that this preference for high AWC should be more pronounced on oligotrophic soils, where more water has to be transpired to transport the same amount of nutrients.

The RSC hypothesis implies that sustainable forest management planning cannot only rely on regional data (or local expert knowledge) but must also include insights from broad scale SDMs that incorporate climate and soil information from the entire species range, including the margins.

The central aim of our study is to test whether temperate trees maintain their water and nutrient supply at the arid southern margin of their distribution range by shifting to more fertile soils with higher water storage. If this soil compensation is effective at the rear edge, it should be evident even based on coarse-gridded coarse-scale data. In testing this hypothesis, we compare statistical species responses with expert knowledge (Ellenberg 1988; Niinemets and Valladares, 2006).

\section{Material and Methods}


196

197

To test the macroecological question of soil compensatory effects at the drier climatic conditions at the rear edge, we combine a large dataset containing more than 270,000 vegetation plots from Central and Southern Europe with ca. 210,000 presence-absence records of temperate species with bioclimatic and edaphic variables derived from WorldClim (Hijmans et al., 2005) and the European Soil Database (ESDB, Panagos et al., 2012).

\section{Target species}

The study focuses on five temperate tree species of economic interest, most of them abundant and widespread in Europe: silver fir (Abies alba Mill.); European beech (Fagus sylvatica L.); Norway spruce (Picae abies (L.) H. Karst.); Scots pine (Pinus sylvestris L.); and sessile oak (Quercus petraea (Mattuschka) Liebl.) (syn. Q. humilis).

Species optima and tolerances to drought (DTOL) and shade (STOL) as well as the nutrient requirements, especially regarding base cation availability are summarized in Table 1. All five species tolerate a wide range of soil conditions from acidic to basic soils (physiological amplitude corresponding to the fundamental niche), while exhibiting narrower and more differentiated requirements in the field (ecological amplitude corresponding to the realized niche, Ellenberg 1988, and descriptions below). STOL is an important trait conveying competitive power (Niinemets and Valladares, 2006), which is negatively correlated to DTOL (Tab. 1). The supplementary material (p. 1) contains more detailed descriptions of species ecology.

\section{Table 1: Species traits}

\section{Tree distribution data}

To represent a gradient from humid to xeric macroclimatic conditions, we collected vegetation plots from Central to Southern Europe (Fig. 1). Cold range margins were represented by including continental ICP Forests data (Fischer et al. 2010) extending to Northern Europe. The resulting sample represents a 
201

202

gradient from subboreal and cold temperate to warm temperate and (sub)mediterranean climates (Table 2). Due to gaps in soil data, especially in Turkey, large areas in South-Eastern Europe could not be included in the analyses. In our analysis it is crucial to distinguish between presence-absence and presence-only data as several data sources (e.g. the European Phenological Database) did not report absence. While frequency distributions (Fig. 2) were extracted from a combination of presence-only (Fig. 1a) and presence-absence data, statistical modeling was solely based on presence-absence data reporting true absences (Fig. 1b). Maps showing an overview about the observed probability of occurrence of the five species in Europe can be found in the supplementary material (Fig. S1-S5).

Figure 1: Plot density in Central and Southern Europe

Table 2: Data overview - Number of plots by countries

\section{Climate data}

We used long-term aggregated climate data (1950-2000) on precipitation and mean temperature from the WorldClim data portal (Hijmans et al., 2005) providing climatic grids at 30 arc-seconds ( 1 km) resolution (in WGS 1984 coordinate system). Similar to Rasztovits (2012), we computed a modified Ellenberg climate quotient (EQ) to represent summer aridity (SA). EQ was originally defined as the ratio of July temperature (in ${ }^{\circ} \mathrm{C}$ ) to annual precipitation (in $\mathrm{mm}$ ) multiplied by 1000 . Despite its simplicity, EQ is a good proxy for climatic drought (Fang and Lechovicz, 2006; Czúcz et al., 2011; Mátyás et al., 2010; Stojanovic et al. 2013) with equal explanatory power in SDMs (Mellert et al., 2016) compared to climatic water balance (cf. Piedallu et al. 2013). For focusing this index on the most limiting summer period (Bréda et al. 2006), we slightly modified the index (EQm) by using the ratio of mean temperature during the warmest quarter $(\mathrm{BIO10})$ to precipitation during the warmest quarter (BIO18) (http://worldclim.org/bioclim). As very low summer precipitation in some regions leads to large numbers, we used the logarithm (LogEQm) in our analyses. 
Within the range of presences of each species LogEQm values were categorized into three different summer ardity levels (SA1-3) by using the 1st and 9th deciles, as done by Alonso-Ponce et al. (2010). The range below the 1st decile represents the humid margin, the interdecile between the 1st and 9th deciles characterizes intermediate or mesic SA conditions (SA2), and the range above the 9th decile represents the most xeric conditions under which the focal species occurs (cf. the xeric margin, SA3) (Fig. 2). This stratification allows for testing and visualizing possible compensatory soil effects by modeling the response of the species along soil gradients under different climatic conditions (see Leuschner et al. 2009 for a similar approach). SA3 values of the study species were highly correlated (Spearman's $r=0.9, p<0.05$ ) to their drought tolerance (DTOL, Table 1).

Figure 2: Boxplot for LogEQm

\section{Soil data}

Soil properties were derived from the European soil database (ESDB, Panagos et al. 2012). Available soil water capacity (AWC, derived according to Hiederer, 2013) was downloaded from the ESDB website (http://eusoils.jrc.ec.europa.eu/content/european-soil-database-derived-data). Both maps are at a scale of 1:1,000,000. The qualitative map of soil types (soil mapping units, SMU) is available as vector data, while AWC data is available as raster data with $1 \mathrm{~km}$ resolution. For explanatory modelling (see below), AWC was stratified into bins of $5 \mathrm{~mm}$ width across the range of AWC values (40-60 $\mathrm{mm}$ ) for which plot density was high (> 15,000 plots), and into bins of $20 \mathrm{~mm}$ width across the range of AWC values for which plot density was lower, resulting in a total of 8 bins (<20, 20-40, 40-45, 45-50, 50-55, 55-60, 60-80, >80 mm). Soil nutrient status (SNS) variable was defined as an ordinal variable with 6 levels characterizing the availability of macro- and micro nutrients in the entire soil profile (Table 3) along a gradient from strongly acidic to calcareous or alkaline soils. Due to acidification and/or substrate stratification chemical properties exhibit characteristic vertical gradients in soil profiles (Kölling et al., 
264

265

266

267

268

1996), resulting in corresponding vertical profiles of nutrient supply (Blume et al., 2016). The soil types derived from the ESDB (Table T1 in the supplementary material) were ordered based on typical chemical properties (Table 3). For soil types with high chemical variation (e.g. Cambisols) parent material and physical properties of the ESDB soil mapping unit were used as auxiliary criteria. In the first step we grouped strongly acidic soils with free aluminium in the soil solution (i), intermediate, moderately acidic soil (ii) and neutral to basic soils with free carbonate in the soil solution (iii). The nutrient supply is unbalanced at the opposite positions of acidity gradient ( $\mathrm{i}$ and $\mathrm{iii}$ ) and tends to be optimal on intermediate soils (ii). Each of these three groups was further divided into two subclasses $(1+2,5+6)$, in order to differentiate weakly and strongly unbalanced nutrient supply, or in the case of the moderately acidic soils, to distinguish between soil with a higher (4) or lower (3) nutrient release rate through weathering. The availability of phosphorous $(\mathrm{P})$ and most trace elements is optimal within the intermediate classes $(3+4)$. Thus, soils with intermediate SNS often combine low base saturation in the topsoil with high base saturation in the subsoil (e.g. most Luvisols), which usually provides a balanced nutrient supply for optimal tree growth (Mellert and Göttlein, 2013).

Table 3: Classification of soil nutrient status

\section{Data aggregation}

To avoid pseudoreplication and spatial autocorrelation of samples (Kühn, 2007), we based our analysis on data aggregated in environmental space. Instead of considering each vegetation plot as an independent observation contributing one degree of freedom per record, we averaged data based on the classes (bins) for SA, AWC and SNS as described above. By doing so, replicated plot observations in geographic space occurring under similar environmental conditions are converted to binary counts in a matrix cell defined by classes of environmental conditions. In this way we can model the probability of occurrence in a structured space of environmental parameters without inflating 
295

the degrees of freedom by pseudoreplicates in geographic space (cf. Austin, 1990). The resulting bins were only considered with a minimum number of 20 plots. The stratification leads to a considerable reduction of sample size and degrees of freedom (number of plots 213,900; number of bins 8 (AWC) $x 6$ (SNS) $\times 3$ (SA) total 144 less bins with no observations results in a N between 105 for $\mathrm{P}$. abies and $\mathrm{N}=115$ for $\mathrm{P}$. sylvestris), but eliminates the risk of type I error (falsely rejecting the null hypothesis of no effect) (Kühn, 2007).

\section{Statistical modelling}

All statistical analyses were computed using the free statistical software $R$ (R Core Team, 2015). Besides using the packages "mgcv" and "PresencesAbsence" (Freeman and Moisen, 2008), we also used the "raster" package for handling gridded data (Hijmans and Etten, 2014).

We tested the relative site constancy (RSC) hypothesis within a gradient analytic perspective on SDMs (Halvorsen et al., 2012). The probability of species occurrence $\left(P_{\text {occ }}\right)$ based on presence-absence data (target variable) was modeled based on the soil variables (AWC and SNS) at the three summer aridity (SA) levels. The response to soil factors at different SA levels was examined by applying spline functions with constrained complexity. Therefore, the degrees of freedom (parameter $k$ in the gam() function from the "mgcv" package in $R(R$ core team 2015, Wood, 2006, 2017)) was restricted to a maximum of four (cf. Mellert et al., 2011) to obtain reasonable and smooth response curves of $P_{\text {occ }}$ along soil gradients, which can be linear, unimodal, or take an u-shaped or sigmoid/saturated form.

We used GAM as implemented in R ( $R$ core team 2015, Wood, 2006, 2017). The "mgcv" algorithm follows the law of parsimony with smoothness selection by the generalized cross validation (GCV) (gam-function arguments: method="GCV.Cp, select=TRUE") criterion resulting in the simplest significant relationship (Wood, 2006, 2017). The overall formula for modeling $P_{\text {occ }}$ of each species is as follows: 


$$
\operatorname{logit}\left(P_{\text {occ }}\right)=\beta_{0}+\beta_{1} * S A 1+\beta_{2} * S A 3+f(A W C) * S A 1+f(A W C) * S A 2+
$$$$
f(A W C) * S A 3+f(S N S) * S A 1+f(S N S) * S A 2+f(S N S) * S A 3
$$

(Equation 1)

Consequently, the model estimates are composed of six smooth functions and three linear parameters $\beta_{0}-\beta_{2}$, where $\beta_{0}$ is the intercept value, and SA2 (medium aridity) is the reference category.

Model adequacy was evaluated using the Akaike information criterion (AIC) and the GCV criterion. GCV was also used for GAM calibration within the "mgcv" algorithm. Golub et al. (1979) introduced GCV as a variant of leave-one-out cross validation. As with AIC, lower values of the GCV score indicate better explanatory power and its values are not linearly related to the proportion of explained variance. Predictive accuracy was evaluated by the area under the curve (AUC) statistic, which is a standard criterion to characterize the fit of binary SDMs (Franklin, 2010) and the true skill statistic (TSS), another criterion that is gaining acceptance in SDMs (Barbet-Massin et al. 2012). TSS ranges from -1 to +1 , where +1 indicates perfect agreement and values of zero or less indicate a performance no better than random (Allouche et al. 2006). Both criteria measure for the ability of a model to classify a species correctly as present or absent in a given data set. While AUC is threshold-independent, TSS relies on a threshold of occurrence (Peterson et al. 2011). We used the prevalence of the species as a threshold as this is a simple and meaningful baseline method (Liu et al. 2005).

As an additional aspect to hypothesis testing, the relevance of soil effects was assessed by comparing the performance of the full model (Equ. 1) to the reference or baseline model only including summer ariditiy (SA). This validation was carried out based on a resampling of the binned data. In a leave-one-out procedure, one bin was left out in each iteration. So the number of iterations equals the number of bins (e.g. 115 for P. sylvestris). AIC and GCV of all resulting models were stored for model validation. The predictive performance (AUC and TSS) was computed using the "PresencesAbsence" package in R (R Core Team, 2015) based on the original (unbinned) data set split into the same portions as 
357 the binned data set (e.g. 1/115 for P. sylvestris). Differences in validation criteria

358 between the full and the baseline model were tested by a T-Test.

$359 \quad$ Although residuals of binary models contain very little information useful

360 for model checking (Wood 2017), we were able to check residuals of our models

361 as they are based on grouped data. These checks generally showed no hints for a

362 serious violation of modelling assumptions.

\section{Results}

\section{Modeling results}

366 The result of modeling is shown in the mosaic plot in Fig. 3, where species

367 define rows and summer aridity levels (SA1-SA3) columns. In each single graph, 368 the effect of the soil physical (AWC, $x$-axis) and chemical gradients (SNS, $y$-axis)

369 on the probability of occurrence $\left(P_{\text {occ }}\right.$, z-axis) at a specific summer aridity level is

370 shown as response surface. Generally, the level of $P_{\text {occ }}$ was higher at

371 intermediate summer aridity (SA2, reference category) compared sites with a

372 higher summer aridity (SA3). However, A. alba, P. abies and F. sylvatica, as

373 typical species of mixed mountain forests, showed similar $P_{\text {occ }}$ under humid (SA1)

374 as under intermediate summer aridity (SA2). Accordingly, $\mathrm{P}_{\text {occ }}$ of $A$. alba and $F$.

375 sylvatica was not significantly different under both conditions, while $\mathrm{P}_{\text {occ }}$ of the

376 boreal P. abies was even higher $(p<0.05)$ under humid conditions (SA1)

377 compared to intermediate aridity (SA2). As a result, the overall effects of the

378 three SA levels on species occurrence were significant $(p<0.05)$ in 13 of 15

379 cases.

380 The soil effects on $\mathrm{P}_{\text {occ }}$ can be recognized as the modification of the general 381 level of $P_{\text {occ }}$ depending on the soil gradients along the $x$-axis (AWC) and $y$-axis 382 (SNS) in Fig. 3, where deviations from a flat surface indicate soil effects. For 383 instance the $\mathrm{P}_{\text {occ }}$ level of $P$. sylvestris was not significantly affected by soil 384 nutrient status at humid sites (SA1). Generally, under humid climatic conditions 385 (SA1) soil effects were most variable, significant for A. alba, F. sylvatica and Q. 386 petraea, only partially for $P$. abies (AWS) and generally insignificant for $P$. 387 sylvestris. 
In contrast, soil compensation effects at high summer aridity levels (SA3, right column) were significant $(p<0.05)$ for all species except the nutrient effect (SNS) on P. sylvestris. Similarly, soil effects at mesic sites (SA2) were all significant except for AWC on P. abies.

For all studied tree species except $Q$. petraea, the response surfaces took quite different shapes depending on the level of SA (Fig. 3). Under mesic conditions (SA2), soil-related response surfaces were unimodal (Q. petraea), plateau- (P. abies) and or u-shaped (A. alba, P. sylvestris). F. sylvatica peaked at intermediate AWC and was invariant to SNS. Response surfaces under mesic conditions (SA2) corresponded to assumed ecological preferences (Table 1) of $F$. sylvatica, P. abies and Q. petraea, but not of $P$. sylvestris and $A$. alba. In accordance with expert knowledge (Table 1), P. abies and F. sylvatica were quite invariant to SNS at intermediate climatic conditions. In contrast, at the xeric margin (SA3), responses of all three drought intolerant species clearly supported a compensatory effect of AWC. In addition, P. abies preferred acidic sites with high water storage and avoided calcareous sites at its xeric margin (SA3).

The drought tolerant tree species, $P$. sylvestris and $Q$. petraea, showed lower $\mathrm{P}_{\text {occ }}$ under low summer aridity (SA1) compared to the intermediate aridity level (SA2). Under mesic conditions (SA2), P. sylvestris occurred most frequently under extreme soils conditions (low and high AWC, low and high SNS). In contrast, at the xeric margin (SA3), its optimum was shifted towards intermediate AWC. Quercus petraea was the only species that showed consistent preference for more acidic soils by avoiding calcareous sites with high AWC at all aridity levels, however, most pronounced at SA3.

Figure 3: Species responses at different SA levels

Accuracy of the full models (Equ. 1) was fair to good according to the AUC classification of Swets (1988) (Table 4). Compared to the purely bioclimatic baseline model inclusion of soil parameters significantly improved the explanatory power (AIC and GCV score) and predictive accuracy (AUC and TSS 
score) of all five studied species $(p<0.05)$. Relative improvements in model quality criteria (\%, AIC, GCV, TSS, AUC) are as follows: Abies alba (40.6, 30.0, 1.2, 5.0); Fagus sylvatica $(21.9,15.9,3.2,3.9)$; Picea abies $(15.4,11.3,0.3,2.6)$ Pinus sylvestris $(47.8,43.6,16.3,9.9)$; and Quercus petraea $(36.8,26.8,6.7,5.7)$.

Table 4: Model evaluation

\section{Discussion}

We found that all studied species except $P$. sylvestris prefer high soil water storage (AWC) under xeric conditions (SA3) (Fig. 3), which suggests a compensatory effect of soil under limiting climatic conditions at the southern margin of temperate tree species distribution, thus supporting the relative site constancy (RSC) hypothesis (Walther, 1973). We are not aware of another macroecological study reporting soil compensatory effects for tree species distribution under limiting climatic aridity at the European scale. These findings might have important implications for expected range shifts of tree species under anthropogenic climate change, including potential lagging effects (cf. extinction lags) (Lenoir and Svenning, 2015) at the trailing edge.

However, the generality of compensatory soil effects is still not entirely clear. Descriptive statistics based on all observed presences showed only few extreme occurrences indicating that high soil water storage allows species to effectively extend their distribution area in arid climates (Fig. 2). This finding is supported by observations from Lopez-Senespleda and Montero (2015), who used a subsample of the Spanish NFI data for which water-holding capacity was estimated.

Further, a major uncertainty of our study is the influence of former management interventions on species distribution patterns. As there is no way of reconstructing those interventions at the scale of our study, effects of management history remain hidden in unexplained variation. Similarly, Leuschner et al. (2009) were unable to take management effects into account in their test of the RSC-hypothesis, comparing distribution centre (Lower Saxony, 
450 Germany) and eastern margin (Slovakia). Marginal populations did not prefer

451 moister and more fertile soils at the astern margin, where, however, annual

452 temperature and precipitation were rather similar to the central distribution

453 area. Therefore Leuschner et al. (2009) hypothesized that cold winters and late

454 frost are more important limiting factors than summer drought at the

455 continental margin.

456 Our study lends partial support to nutrient effects. Although compensatory

457 effects of AWC were most pronounced at oligotrophic sites (SNS=1), observed

458 minima of this effect did not correspond to suggested physiological maxima

459 under well balanced nutrient supply (SNS 3-4) (Ellenberg, 1988; Niinements and

460 Valladares, 2006), except for $A$. alba. $P_{\text {occ }}$ of $P$. sylvestris and $Q$. petraea under

461 xeric climate appeared to reflect ecological rather than physiological preferences

462 (Ellenberg 1988), lending further support to the importance of biotic interactions

463 (Leuschner et al., 2009; Meier et al., 2010) at the rear edge. This finding is

464 underpinned by demographic studies (e.g. Lakatos and Molnár, 2009; Benito-

465 Garzon et al., 2013) as well as by comparisons between SDMs and process-based

466 models (e.g. Serra-Diaz et al., 2013). Apparently, shade tolerant temperate tree

467 species such as F. sylvatica (Ellenberg, 1988) loose competitive power close to

468 their xeric sub-Mediterranean limits, allowing more light-demanding oaks and

469 pines to occupy more favorable soils (higher AWC and SNS). This result is in

470 accordance with Serra-Diaz et al. (2013), who found a positive correlation of $P_{\text {occ }}$

471 and productivity of $P$. sylvestris in Spain, which is not found in Central Europe

472 (Ellenberg, 1988). Consistent to our findings on species ranges along the summer

473 aridity gradient (Fig. 2), recent studies (Ligot et al., 2013; Tegel et al., 2014;

474 Sánchez-De Dios et al. 2016) show that the drought tolerance of $F$. sylvatica

475 might have been underestimated in earlier literature (Niinemets and Valladres,

476 2006; Table 1).

477 Quercus petraea can also occupy soils with high AWC in a xeric climate, but

478 avoids carbonate soils (see Table 1, physiological and ecological optima). This

479 distribution can be related to niche partitioning between Q. petraea (acidic) and

480 Q. pubescens (basic soils) at dry sites (Ellenberg, 1988). Besides competition, 


\section{Conclusions}

505

southern limits of temperate species can be co-determined by pests, e.g. by Ips typographus or Heterobasidion annosum for P. abies (Caudullo et al., 2016). The response of $P$. abies supports Central European expert opinion (Falk et al., 2013) that this boreal species is endangered by $H$. annosum infestations on carbonate soils under warm conditions ( $>7.5^{\circ} \mathrm{C}$ in mean annual temperature). The examples of $P$. abies preferring acidic soils with high AWC and $P$. sylvestris preferring intermediate AWC at high summer aridity (SA3) show that, at the xeric margin, soil compensation may lead to habitat preferences considerably different from Central European experience, as laid down in Ellenberg ecograms (Ellenberg, 1988).

Our findings supporting the RSC hypothesis question the traditional assumption that tree species distribution at the continental extent can be estimated from climatic variables alone (Whittaker 1970), but supports the more recent finding that soil properties matter for macroecology (Thuiller, 2013; Diekmann et al., 2015). The relatively modest improvements in model performance can be related to (1) the coarse spatial resolution of the soil grid, leading to an underestimation of predictive capacity, and (2) to the interference of biotic interactions (competition and pests, see below) and human impacts (especially forest management). These remaining uncertainties and limitations could be addressed based on the ICP Forests monitoring network (Seidling 2016, Bussotti and Pollastrini 2017), if complemented by rear edge populations of important European tree species, at best in a spatially nested design.

With respect to available water content, macroecological analysis supports the relative site constancy hypothesis in terms of statistical significance and plausibility of soil compensatory effects on tree species distribution under limiting climatic conditions. The inclusion of soil significantly improves explanatory power and predictive performance of models. The contribution of soil parameters is most obvious for $P$. sylvestris, $Q$. petraea and A. alba. 
Our findings imply that tree species ecology cannot be understood from

512 isolated case studies at the rear edge. Therefore, work is needed to expand our

513 knowledge on the importance of soil compensatory effects to a larger number of

514 tree species using models that do also account for biotic interactions and human

515 impacts. Combining studies of continental extent with high-resolution species

516 occurrence and environmental information remains a considerable challenge.

517 This study points to opportunities and current limits of such an approach.

\section{References}

Alonso-Ponce R, López Senespleda E, Sánchez Palomares O (2008) A novel application of the ecological field theory to the definition of physiographic and climatic potential areas of forest species. Eur J Forest Res 129:119-131.

Attorre F, Alfò M, Sanctis M de et al (2011) Evaluating the effects of climate change on tree species abundance and distribution in the Italian peninsula. Appl Veg Sci

$$
14: 242-255
$$

Austin MP (1980) Searching for a model for use in vegetation analysis. Vegetatio 42:1121.

Austin MP, Nicholls AO, Margules CR (1990) Measurement of the realized qualitative niche: environmental niches of five Eucalyptus species. Ecol Monogr 60:161-177

Bailey RG (1987) Suggested hierarchy of criteria for multi-scale ecosystem mapping. Landscape Urban Plan 14:313-319

Barbet-Massin M, Jiguet F, Albert CH et al (2012) Selecting pseudo-absences for species distribution models: how, where and how many? Methods Ecol Evol 3:327-338

Barnes BV, Pregitzer KS, Spies TA et al (1982) Ecological Forest Site Classification. J Forest 80:493-498

Beauregard F, Blois S de (2014) Beyond a climate-centric view of plant distribution: edaphic variables add value to distribution models. PloS one 9:e92642

Benito-Garzón M, Ruiz-Benito P, Zavala MA (2013) Interspecific differences in tree growth and mortality responses to environmental drivers determine potential species distributional limits in Iberian forests. Global Ecol Biogeogr 22:1141-1151

Bertrand R, Perez V, Gégout J-C (2012) Disregarding the edaphic dimension in species distribution models leads to the omission of crucial spatial information under climate change: the case of Quercus pubescens in France. Glob Change Biol 18:26482660 
545

546

547

548

549

550

Binkley D, Vitousek P (1989) Soil nutrient availability. In: Pearcy RW, Ehleringer JR,

$$
\text { Mooney HA et al (eds) Plant Physiological Ecology. Field methods and }
$$
instrumentation. Springer Netherlands, Dordrecht, pp 75-96

Blume H-P, Brümmer GW, Fleige H et al (2015) Scheffer/Schachtschabel soil science. Springer

Bohn U, Neuhäusl R, Gollub G, Hettwer C, Neuhäuslova Z, Raus T, Schlüter H, Weber H (2003) Map of the natural vegetation of Europe, scale 1:2500000. Parts 1-3. Landwirtschaftsverlag, Münster-Hiltrup

Bradbury IK, Malcolm DC (1977) The effect of phosphorus and potassium on transpiration, leaf diffusive resistance and water-use efficiency in Sitka spruce (Picea sitchensis) seedlings. J Appl Ecol:631-641

Bréda N, Huc R, Granier A et al (2006) Temperate forest trees and stands under severe drought. A review of ecophysiological responses, adaptation processes and longterm consequences. Ann For Sci 63:625-644

Brus DJ, Hengeveld GM, Walvoort DJ et al (2011) Statistical mapping of tree species over Europe. Eur J Forest Res 131:145-157.

Bussotti F, Pollastrini M (2017) Observing climate change impacts on European forests: what works and what does not in ongoing long-term monitoring networks. Front Plant Sci 8.

Cajander AK (1949) Forest types and their significance. Acta Forestalia Fennica 56:1-71 Caudullo, G., Tinner, W., de Rigo, D. (2016) Picea abies in Europe: distribution, habitat, usage and threats. In: San-Miguel-Ayanz, J., de Rigo, D., Caudullo, G., Houston Durrant, T., Mauri, A. (Eds.), European Atlas of Forest Tree Species. Publ. Off. EU, Luxembourg, pp. e012300+.

Coudun C, Gégout J-C, Piedallu C et al (2006) Soil nutritional factors improve models of plant species distribution. An illustration with Acer campestre (L.) in France. J Biogeogr 33:1750-1763

Czúcz B, Gálhidy L, Mátyás C (2011) Present and forecasted xeric climatic limits of beech and sessile oak distribution at low altitudes in Central Europe. Ann For Sci 68:99108.

Diekmann M, Michaelis J, Pannek A (2015) Know your limits - The need for better data on species responses to soil variables. Basic Appl Ecol 16:563-572 
577

578

579

580

581

582

583

584

585

586

587

588

589

590

591

592

593

594

595

596

597

598

599

600

601

602

603

604

605

606

607

608

609

Dolos K, Bauer A, Albrecht S (2015) Site suitability for tree species. Is there a positive relation between a tree species' occurrence and its growth? Eur J Forest Res 134:609-621.

Dubuis A, Giovanettina S, Pellissier L et al (2013) Improving the prediction of plant species distribution and community composition by adding edaphic to topo-climatic variables. J Veg Sci 24:593-606

Ducousso A, Bordacs S (2004) EUFORGEN technical guidelines for genetic conservation and use for pedunculate and sessile oaks. Quercus robur and $Q$. petraea

Dullinger S, Gattringer A, Thuiller W et al (2012) Extinction debt of high-mountain plants under twenty-first-century climate change. Nat Clim Change 2:619-622

Ellenberg H, Leuschner C (2010) Vegetation Mitteleuropas mit den Alpen. Verlag Eugen Ulmer, Stuttgart

Ellenberg H (1988) Vegetation ecology of central Europe. Cambridge University Press, Cambridge

Ewald J, Hédl R (2014) Spatial Modeling of Vegetation Potential. An Introduction. Folia Geobot 49:309-312

Falk W, Mellert K, Bachmann-Gigl U et al (2013) Bäume für die Zukunft: Baumartenwahl auf wissenschaftlicher Grundlage. LWF aktuell 94:8

Falk W, Mellert KH (2011) Species distribution models as a tool for forest management planning under climate change: risk evaluation of Abies alba in Bavaria. J Veg Sci 22:621-634

Fang J, Lechowicz MJ (2006) Climatic limits for the present distribution of beech (Fagus

L.) species in the world. J Biogeogr 33:1804-1819

Fischer R, Lorenz M, Granke O et al Forest condition in Europe: 2010 technical report of ICP forests

Franklin J (2010) Mapping Species Distributions: Spatial Inference and Prediction. Cambridge University Press, Cambridge

Freeman EA, Moisen G (2008) PresenceAbsence: An R package for presence absence analysis

Golub GH, Heath M, Wahba G (1979) Generalized cross-validation as a method for choosing a good ridge parameter. Technometrics 21:215-223

Guisan A, Zimmermann NE (2000) Predictive habitat distribution models in ecology. Ecol Model 135:147-186 
610

611

612

613

614

615

616

617

618

619

620

621

622

623

624

625

626

627

628

629

630

631

632

633

634

635

636

637

638

639

640

641

Halvorsen R (2012) A gradient analytic perspective on distribution modelling. Sommerfeltia 35:1-165

Hanewinkel M, Cullmann DA, Michiels H-G et al (2014) Converting probabilistic tree species range shift projections into meaningful classes for management. J Environ Manage 134:153-165

Hiederer R (2013) Mapping soil properties for Europe-spatial representation of soil database attributes. Publications Office of the European Union, EUR26082EN Scientific and Technical Research series. Luxembourg

Hijmans RJ, Cameron SE, Parra JL et al (2005) Very high resolution interpolated climate surfaces for global land areas. Int J Climatol 25:1965-1978

Hijmans RJ, van Etten J (2014) raster: Geographic data analysis and modeling. R package version 2.2-31.

Hlásny T, Mátyás C, Seidl R et al (2014) Climate change increases the drought risk in Central European forests: What are the options for adaptation? Forestry Journal $60: 5-18$

Kölling C, Hoffmann M, Gulder H-J (1996) Bodenchemische Vertikalgradienten als charakteristische zustandsgrössen von waldökosystemen. Z Pflanz Bodenkunde 159:69-77

Kühn I (2007) Incorporating spatial autocorrelation may invert observed patterns. Divers Distrib 13:66-69

Lakatos F, Molnár M (2009) Mass mortality of beech (Fagus sylvatica L.) in South-West Hungary. Acta Silvatica et Lignaria Hungarica 5:75-82

Latron J, Llorens P, Gallart F (2009) The hydrology of Mediterranean mountain areas. Geography Compass 3:2045-2064

Leibundgut $\mathrm{H}$ (1984) Unsere Waldbäume. Eigenschaften und Leben. Huber, Frauenfeld

Lenoir J, Hattab T, Pierre G (2017) Climatic microrefugia under anthropogenic climate change: implications for species redistribution. Ecography 40:253-266

Lenoir J, Svenning J-C (2015) Climate-related range shifts-a global multidimensional synthesis and new research directions. Ecography 38:15-28 Lenoir J, Svenning J-C, Dullinger S et al (2012) The Alps Vegetation Database-a georeferenced community-level archive of all terrestrial plants occurring in the Alps. Biodiversity and Ecology 4:331-332 
642

643

644

645

646

647

648

649

650

651

652

653

654

655

656

657

658

659

660

661

662

663

664

665

666

667

668

669

670

671

672

673

674

Leuschner C, Köckemann B, Buschmann H (2009) Abundance, niche breadth, and niche occupation of Central European tree species in the centre and at the margin of their distribution range. Forest Ecol Manag 258:1248-1259

Ligot G, Balandier P, Fayolle A et al (2013) Height competition between Quercus petraea and Fagus sylvatica natural regeneration in mixed and uneven-aged stands. Forest Ecol Manag 304:391-398

Lopez-Senespleda E, Montero G Tipificación Ecológico-Selvícola de las Principales Especies Forestales Españolas, Madrid, Spain

Mátyás C, Ackzell L, Samuel CJA (2004) EUFORGEN technical guidelines for genetic conservation and use for Scots pine (Pinus sylvestris). Bioversity International

Mátyás C, Berki I, Czúcz B et al (2010) Future of beech in Southeast Europe from the perspective of evolutionary ecology. Acta Silvatica et Lignaria Hungarica 6:91-110

Meier ES, Kienast F, Pearman PB et al (2010) Biotic and abiotic variables show little redundancy in explaining tree species distributions. Ecography 33:1038-1048

Mellert KH, Ewald J (2014) Nutrient limitation and site-related growth potential of Norway spruce (Picea abies [L.] Karst) in the Bavarian Alps. Eur J Forest Res 133:433451

Mellert KH, Fensterer V, Küchenhoff $\mathrm{H}$ et al (2011) Hypothesis-driven species

distribution models for tree species in the Bavarian Alps. J Veg Sci 22:635-646

Mellert KH, Göttlein A (2013) Identification and validation of thresholds and limiting nutrient factors of Norway spruce by using new nutritional levels and modern regression. Allg Forst Jagdztg 184:197-203

Mellert KH, Deffner V, Küchenhoff $\mathrm{H}$ et al (2015) Modeling sensitivity to climate change and estimating the uncertainty of its impact. A probabilistic concept for risk assessment in forestry. Ecol Model 316:211-216

Mellert KH, Ewald J, Hornstein D et al (2016) Climatic marginality: a new metric for the susceptibility of tree species to warming exemplified by Fagus sylvatica (L.) and Ellenberg's quotient. Eur J Forest Res 135:137-152

Nieto-Lugilde D, Lenoir J, Abdulhak S et al (2015) Tree cover at fine and coarse spatial grains interacts with shade tolerance to shape plant species distributions across the Alps. Ecography 38:578-589

Niinemets Ü, Valladares F (2006) Tolerance to shade, drought, and waterlogging of temperate northern hemisphere trees and shrubs. Ecol Monogr 76:521-547 
675

676

677

678

679

680

681

682

683

684

685

686

687

688

689

690

691

692

693

694

695

696

697

698

699

700

701

Panagos P, van Liedekerke M, Jones A et al (2012) European Soil Data Centre: Response to European policy support and public data requirements. Land Use Policy 29:329338

Piedallu C, Gégout J, Perez V et al (2013) Soil water balance performs better than climatic water variables in tree species distribution modelling. Glob Ecol and Biogeogr 22:470-482

Piedallu C, Gégout J-C, Lebourgeois F et al (2016) Soil aeration, water deficit, nitrogen availability, acidity and temperature all contribute to shaping tree species distribution in temperate forests. J Veg Sci:387-399

Rasztovits E, Moricz N, Berki l et al (2012) Evaluating the performance of stochastic distribution models for European beech at low-elevation xeric limits. Idojárás 116:173-194

Sánchez De Dios R, Hernández L, Montes F et al (2016) Tracking the leading edge of Fagus sylvatica in North-Western Iberia: Holocene migration inertia, forest succession and recent global change. Perspect Plant Ecol 20:11-21

Serra-Diaz JM, Keenan TF, Ninyerola M et al (2013) Geographical patterns of congruence and incongruence between correlative species distribution models and a processbased ecophysiological growth model. J Biogeogr 40:1928-1938

Stojanović DB, Kržič A, Matović B et al (2013) Prediction of the European beech (Fagus sylvatica L.) xeric limit using a regional climate model. An example from southeast Europe. Agr Forest Meteorol 176:94-103

Tegel W, Seim A, Hakelberg D et al (2014) A recent growth increase of European beech (Fagus sylvatica L.) at its Mediterranean distribution limit contradicts drought stress. Eur J Forest Res 133:61-71.

Thuiller W (2013) On the importance of edaphic variables to predict plant species distributions - limits and prospects. J Veg Sci 24:591-592

Tsiripidis I, Bergmeier E, Fotiatidis G et al (2012) Hellenic Beech Forests Database (HellBeech-DB)

Walter H (1973) Vegetation of the earth in Relation to Climate and the Eco-Physiological Conditions. English Universities Press

Whittaker RH (1970) Communities and ecosystems. Macmillan, London

Wolf H (2003) EUFORGEN Technical Guidelines for genetic conservation and use for for silver fir (Abies alba). Bioversity International 
708 Wood S (2006) Generalized additive models: an introduction with R. CRC press, Boca 709 Raton

710 Wood S (2017) Mixed GAM Computation Vehicle with Automatic Smoothness

711 Estimation. R-reference manual.

712 Zimmermann NE, Jandl R, Hanewinkel M et al (2013) Chapter 4 Potential future ranges

713 of tree species in the Alps. In: Cerbu GA, Hanewinkel M, Gerosa G, Jandl R (eds)

714 Management Strategies to Adapt Alpine Space Forests to Climate Change Risks,

715 InTech, Chapters published August 28, 2013 under CC BY 3.0 license DOI:

$716 \quad 10.5772 / 56933$ 
717 Table 1: Tree species-related information on shade tolerance (STOL), drought

718 tolerance (DTOL) according to Niinemets and Valladares (2006), physiological

719 optimum with respect to soil acidity according to Ellenberg (1988) and the

720 corresponding approximate range of the soil nutrient status (SNS) (see Table 3).

721

\begin{tabular}{lrrrrrr}
\hline Species & \multicolumn{2}{c}{$\begin{array}{c}\text { Tolerance } \\
\text { Shade } \\
\text { (STOL) }\end{array}$} & $\begin{array}{c}\text { Drought } \\
\text { (DTOL) }\end{array}$ & \multicolumn{2}{c}{$\begin{array}{c}\text { Physiological optimum } \\
\text { in the soil gradient }\end{array}$} & \multicolumn{2}{c}{ Ecological optimum } \\
& \multicolumn{8}{c}{$\begin{array}{c}\text { according to } \\
\text { Ecogram }\end{array}$} & $\begin{array}{c}\text { approx. } \\
\text { SNS range }\end{array}$ & $\begin{array}{c}\text { according to } \\
\text { Ecogram }\end{array}$ & $\begin{array}{c}\text { approx. } \\
\text { SNS range }\end{array}$ \\
Aalba & 4.6 & 1.81 & base rich & $2-6$ & not specified & \\
Fsylv & 4.56 & 2.4 & base rich & $2-6$ & invariant & $1-6$ \\
Pabie & 4.45 & 1.75 & intermediate & $2-5$ & not specified & \\
Psylv & 1.67 & 4.34 & intermediate & $2-4$ & calcareous; acidic & 1,6 \\
Qpetr & 2.73 & 3.02 & base rich & $2-5$ & acidic & $1-3$ \\
\hline
\end{tabular}


Table 2: Sample regions, data sources, and numbers of plots.

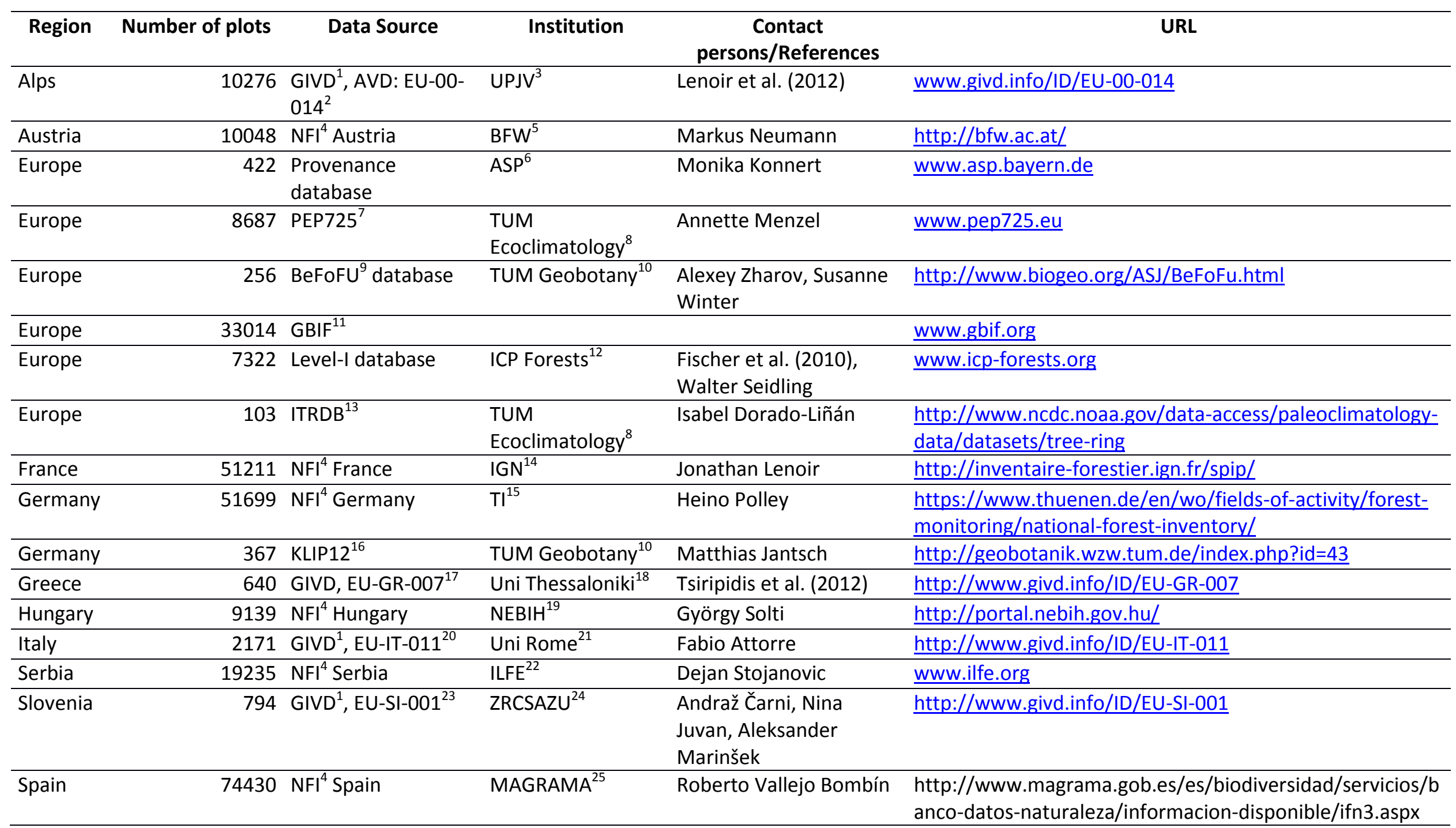


No. Institution (Abbreviation)

1

2

3 UPJV

5 BFW

6 ASP

7

8 TUM

Ecoclimatology

9 TUM

Ecoclimatolog

10 TUM Geobotany

11

ICP Forests

IGN

$\mathrm{TI}$

16

8 Uni Thessaloniki

$\mathrm{NEBIH}$

Uni Rome

ILFE

23

4 ZRCSAZU

5 MAGRAMA
4 Diverse Institution

Data Source

(Abbreviation)

GIVD

AVD: EU-00-014

$\mathrm{NFI}^{4}$

NFI Austria

Provenance database

PEP725

BeFoFU database

GBIF

Level-I database

ITRDB

NFI France

NFI Germany

KLIP12

EU-GR-007

NFI Spain

NFI Hungary

EU-IT-011

EU-SI-001

\section{Full names of Institution / Data source}

Global Index of Vegetation-Plot Databases

The Alps Vegetation Database

Université de Picardie Jules Verne (Amiens, France)

National Forest Invetory

Bundesforschungszentrum für Wald

Bayerisches Amt für forstliche Saat- und Pflanzenzucht

European Phenological Database

Technische Universität München, Professorship of Ecoclimatology

European Beech Forests for the Future

Technische Universität München, Professorship of Geobotany

Global Biodiversity Information Facility

International Co-operative Programme on Assessment and Monitoring of Air Pollution Effects on Forests

International Tree-Ring Data Bank

Institut National de l'Information Géographique et Forestière (Paris, France)

Thünen Institute of Forest Ecosystems

Klimaprogramm Bayern

Hellenic Beech Forest Database

Aristotle University of Thessaloniki

National Food Chain Safety Office

Vegetation Plot Database Sapienza University of Rome

Sapienza University of Rome

Institute of Lowland Forestry and Environment, University of Novi Sad

Vegetation Database of Slovenia

Research Center of the Slovenian Academy of Sciences and Arts

Ministerio de Agricultura, Alimentación y Medio Ambiente 
Table 3: Soil chemical properties used for classification of the soil nutrient status (SNS) of terrestrial soil types of the European Soil Database (ESDB, Panagos 2012). For classification of soil types see Table T1 in the supplementary material.

\begin{tabular}{|c|c|c|c|c|c|}
\hline $\begin{array}{c}\text { Index } \\
\text { number }\end{array}$ & $\begin{array}{l}\text { Soil nutrient } \\
\text { status (SNS) }\end{array}$ & $\begin{array}{c}\text { Short characteristic } \\
\text { determining the nutrition } \\
\text { status }\end{array}$ & Soil reaction & $\begin{array}{l}\text { Base saturation } \\
\text { and ionic } \\
\text { strenght }\end{array}$ & $\begin{array}{l}\text { Typical nutrient } \\
\text { deficiencies for not } \\
\text { adapted plants }\end{array}$ \\
\hline 2 & $\begin{array}{l}\text { oligotrotrophic } \\
\text { meso-oligotrophic }\end{array}$ & $\begin{array}{l}\text { unbalances nutrition with } \\
\text { free aluminum }\end{array}$ & $\begin{array}{l}\text { moderately to } \\
\text { strong acid }\end{array}$ & low & $\mathrm{P}, \mathrm{Ca}, \mathrm{Mg}$, partly $\mathrm{N}$ \\
\hline 4 & $\begin{array}{l}\text { mesotrophic } \\
\text { eutrophic }\end{array}$ & $\begin{array}{c}\text { balanced nutrition without a } \\
\text { dominating cation or anion } \\
\text { in soil solution or induced } \\
\text { nutrition deficiency }\end{array}$ & $\begin{array}{l}\text { moderately acid } \\
\text { to neutral }\end{array}$ & $\begin{array}{l}\text { Intermediate to } \\
\text { high }\end{array}$ & no deficiencies \\
\hline 6 & $\begin{array}{l}\text { calcareous meso- } \\
\text { oligotrophic } \\
\text { calcareous } \\
\text { oligotrophic }\end{array}$ & $\begin{array}{l}\text { unbalances nutrition with } \\
\text { free carbonate }\end{array}$ & $\begin{array}{l}\text { slightly acid to } \\
\text { slightly neutral }\end{array}$ & high & $\mathrm{P}, \mathrm{K}, \mathrm{Fe}, \mathrm{Mn}$, partly $\mathrm{N}$ \\
\hline
\end{tabular}




\begin{tabular}{llllll}
\hline Species & \multicolumn{1}{c}{ Model } & \multicolumn{1}{c}{ AIC } & \multicolumn{1}{c}{ GCV } & \multicolumn{1}{c}{ TSS } & AUC \\
\hline Aalba & SA only & $7829.793 \pm 1.33 \mathrm{e}+02$ & $73.673 \pm 1.33 \mathrm{e}+00$ & $0.594 \pm 2.55 \mathrm{e}-02$ & $0.801 \pm 1.32 \mathrm{e}-02$ \\
& Full & $4652.257 \pm 1.26 \mathrm{e}+02$ & $51.604 \pm 1.35 \mathrm{e}+00$ & $0.601 \pm 2.13 \mathrm{e}-02$ & $0.841 \pm 1.16 \mathrm{e}-02$ \\
\hline \multirow{2}{*}{ Fsylv } & SA only & $14215.162 \pm 2.51 \mathrm{e}+02$ & $130.175 \pm 2.41 \mathrm{e}+00$ & $0.473 \pm 1.81 \mathrm{e}-02$ & $0.741 \pm 9.49 \mathrm{e}-03$ \\
& Full & $11101.638 \pm 2.6 \mathrm{e}+02$ & $109.523 \pm 2.66 \mathrm{e}+00$ & $0.488 \pm 1.92 \mathrm{e}-02$ & $0.77 \pm 1.23 \mathrm{e}-02$ \\
\hline Pabie & SA only & $15593.006 \pm 3.39 \mathrm{e}+02$ & $153.214 \pm 3.45 \mathrm{e}+00$ & $0.681 \pm 1.5 \mathrm{e}-02$ & $0.848 \pm 7.21 \mathrm{e}-03$ \\
& Full & $13189.302 \pm 3.01 \mathrm{e}+02$ & $135.91 \pm 3.05 \mathrm{e}+00$ & $0.683 \pm 1.87 \mathrm{e}-02$ & $0.87 \pm 9.4 \mathrm{e}-03$ \\
\hline Psylv & SA only & $15784.848 \pm 4.25 \mathrm{e}+02$ & $138.681 \pm 3.89 \mathrm{e}+00$ & $0.276 \pm 2.27 \mathrm{e}-02$ & $0.648 \pm 1.18 \mathrm{e}-02$ \\
& Full & $8247.45 \pm 3.2 \mathrm{e}+02$ & $78.167 \pm 2.85 \mathrm{e}+00$ & $0.321 \pm 2.8 \mathrm{e}-02$ & $0.712 \pm 1.45 \mathrm{e}-02$ \\
\hline \multirow{2}{*}{ Qpetr } & SA only & $12454.258 \pm 1.95 \mathrm{e}+02$ & $110.706 \pm 1.81 \mathrm{e}+00$ & $0.388 \pm 2.99 \mathrm{e}-02$ & $0.703 \pm 1.45 \mathrm{e}-02$ \\
& Full & $7864.95 \pm 1.95 \mathrm{e}+02$ & $81.027 \pm 1.83 \mathrm{e}+00$ & $0.414 \pm 2.42 \mathrm{e}-02$ & $0.743 \pm 1.37 \mathrm{e}-02$ \\
\hline
\end{tabular}

Table 4 Results of the model evaluation involving the Akaike information criterion (AIC), the generalized cross validation criterion (GCV) the true skill statisitic (TSS) and the area under the curve statistic (AUC). The validation is based on a leave-one-out resampling of the binned data. The table entries show the mean \pm standard deviation of model quality criteria. For all species criteria are statistically different for 'SA only' and 'Full models' $(p<0.05)$. 
737 Figure 1: Plot density of presence-only records (Figure 1a upper panel) and plot

738 density of presence-absence recods (Figure $1 b$ lower panel) in Southern and

739 Central Europe as well as adjacent regions in a $16 \times 16 \mathrm{~km}$ grid. In Northern Europe

740 the plots density is constantly low (ca. 1 plot per grid cell, light grey).

741

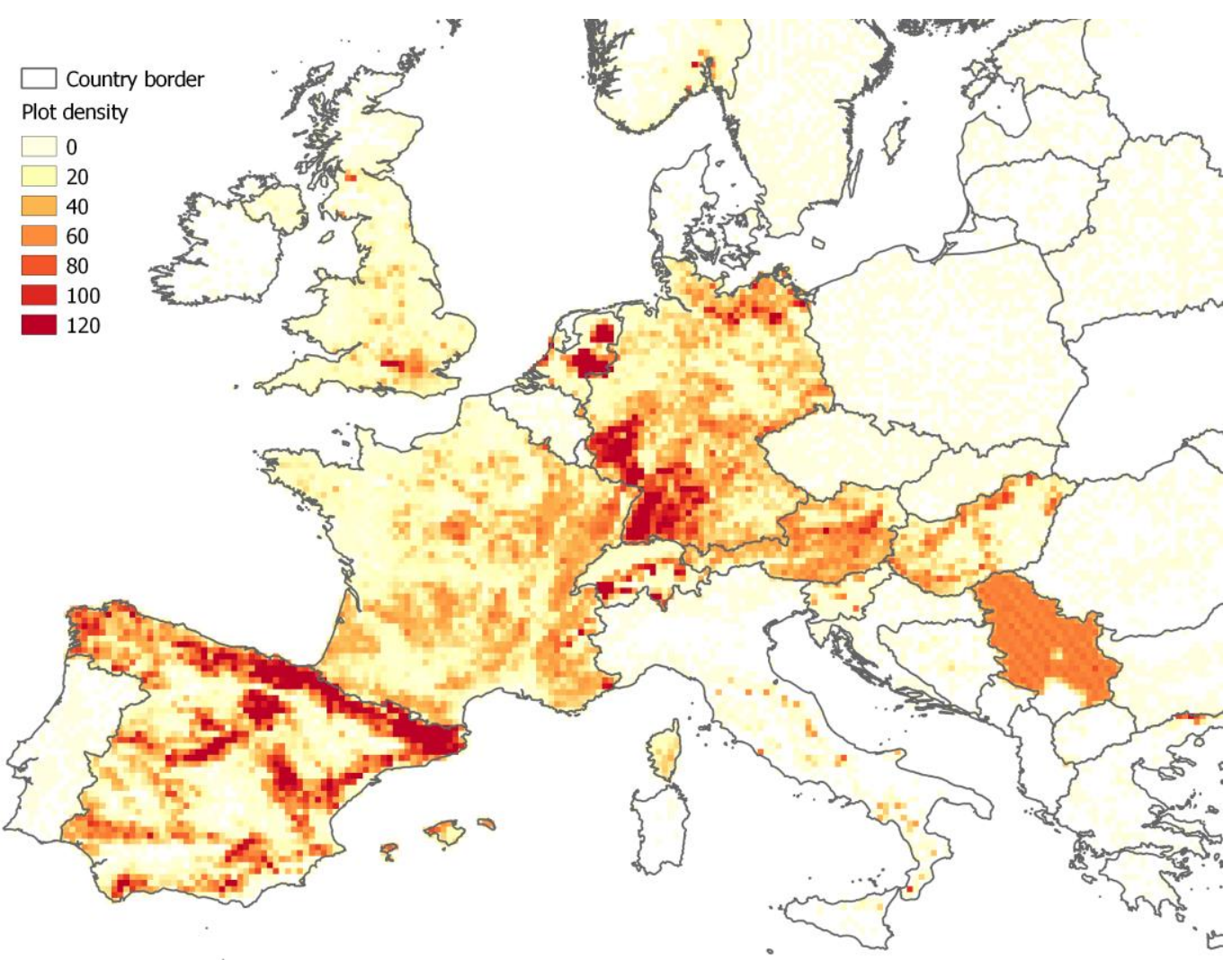




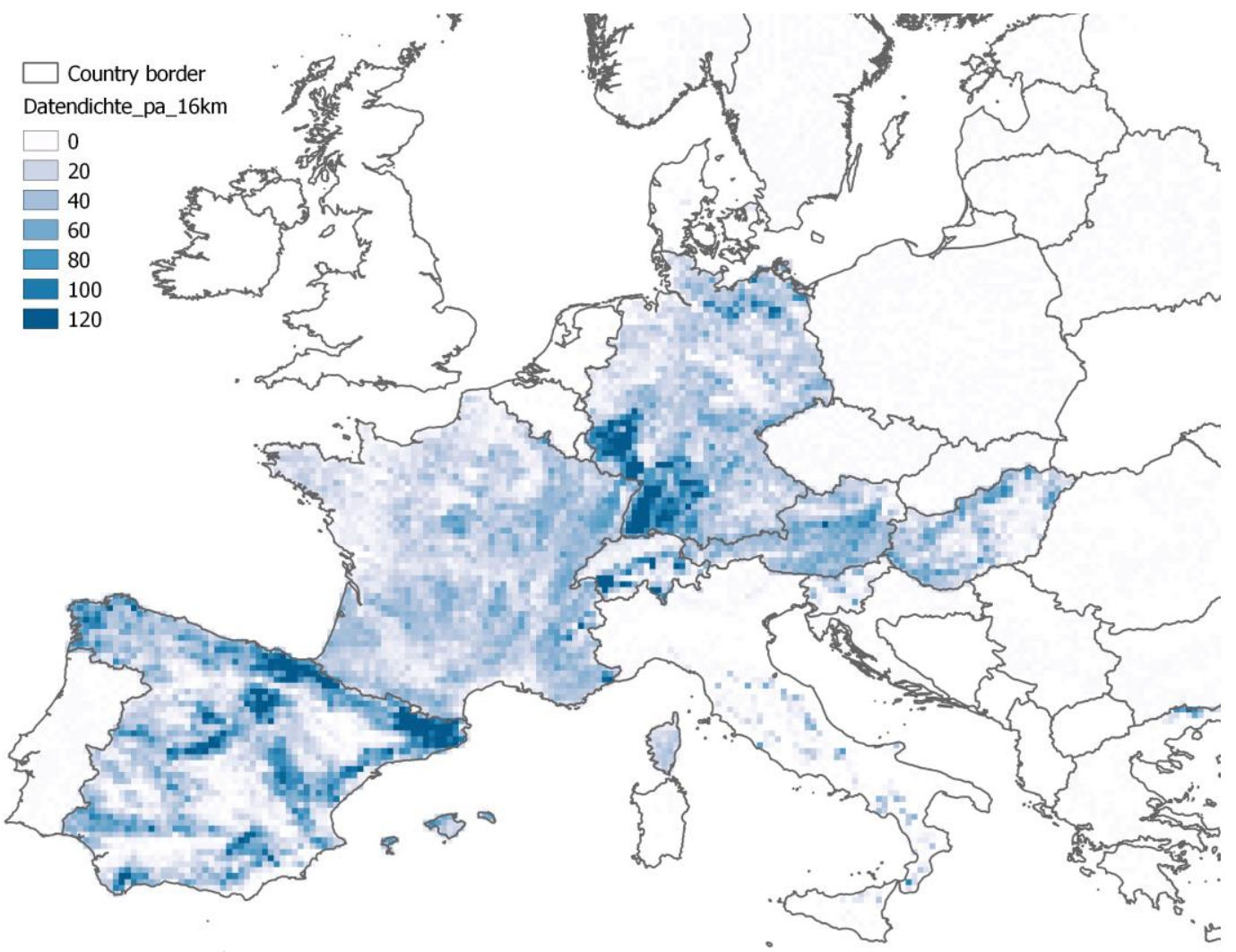


745 Figure 2: Frequency distribution of the modified Ellenberg's quotient (LogEQm)

746 indicating summer aridity for five major forest tree species of Central Europe

747 (Abies alba = Aalba, Fagus sylvatica $=$ Fsylv, Picea abies $=$ Pabie, Pinus sylvestris =

748 Psylv, Quercus petraea = Qpetr). Boxplots represent data as stratified for the

749 analysis: Values between the lower and upper whiskers represent range of the

750 second decile to the $9^{\text {th }}$ decile (SA2). Accordingly, points below the lower whisker

751 represent the $1^{\text {st }}$ decile (SA1, humid climatic conditions) and points above the

752 upper whisker represent the $10^{\text {th }}$ decile (SA3, xeric climatic conditions). Red

753 squares in the boxplots of tree species indicate sites under high summer aridity

754 where species only occur under a high available water capacity of the soil (> 50

$755 \mathrm{~mm}$ ). Total number of plots usable as presence-only records $=278,814$.

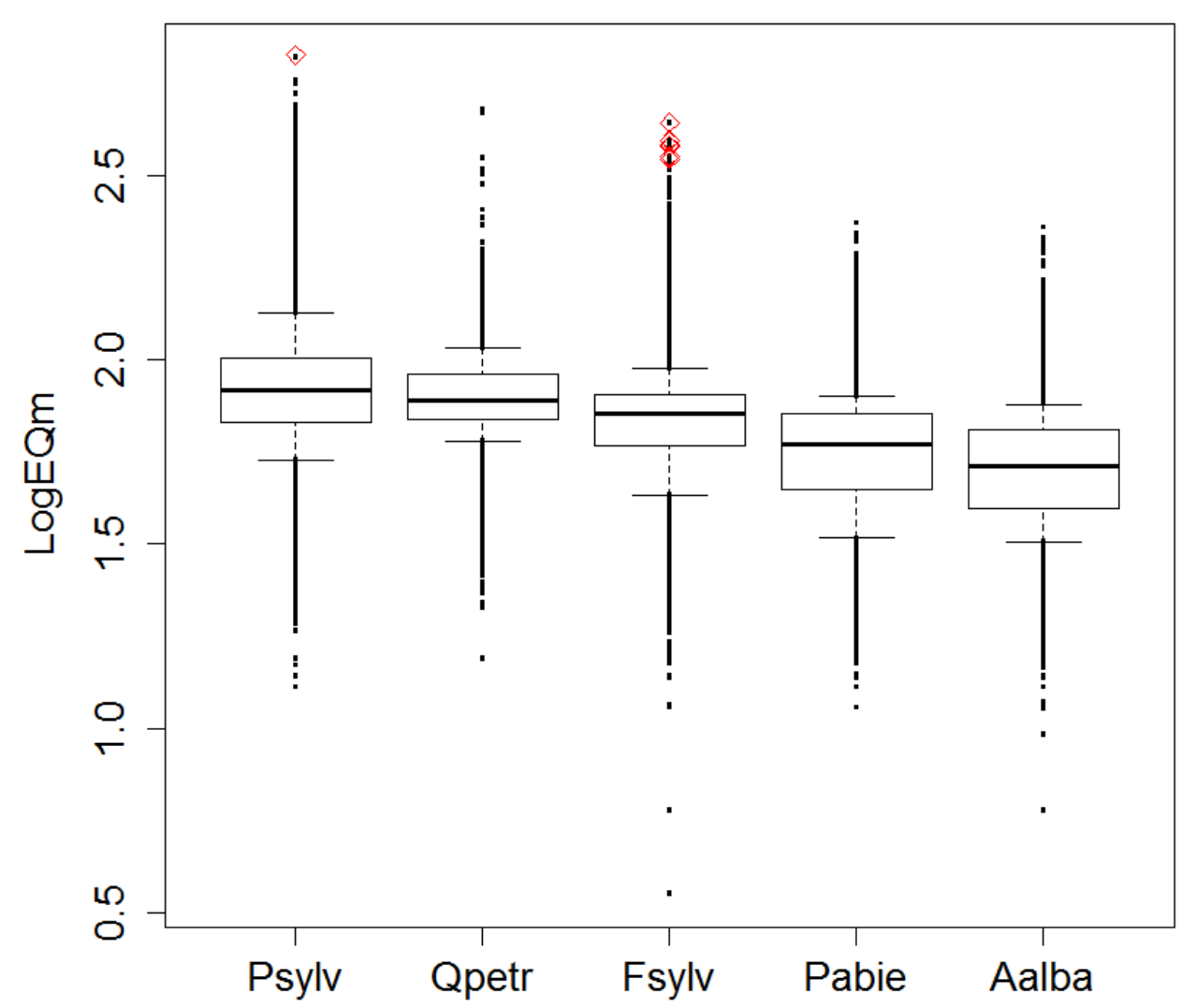


757 Figure 3: Results of the model for the five tree species from the top in

758 alphabetical order (Aalba to Qpetr, species abbreviations see Figure 1). All graphs

759 show the response surface of the probability of occurrence $\left(P_{\text {occ }}\right)$ against available

760 water capacity (AWC) and soil nutrient status (SNS). First column: Mean $P_{\text {occ }}$ at

761 the summer aridity level at $1^{\text {st }}$ decile (humid climate, SA1); Second column: Mean

$762 P_{\text {occ }}$ at 2.-9. decile (intermediate climate, SA2); Third column: Mean $P_{\text {occ }}$ at the

763 summer aridity level at 10th decile (xeric climate, SA3). Number of presence-

764 absence records 213,900 are reduced by data aggregation to 107 (Aalba), 112

765 (Fsylv), 105 (Pabie), 115 (Psy/v), 114 (Qpetr). All main effects of the models are

766 significant $(p<0.05)$, except $\beta_{1}$ for SA1 of Aalba and Fsylv (see Equ. 1). AWC and

767 SNS effects in a xeric climate (SA3, right column) indicating possible

768 compensation by the soil are significant for all species except SNS for Psylv.

769

770 
Climate: Humid (SA1)

Species:

Aalba

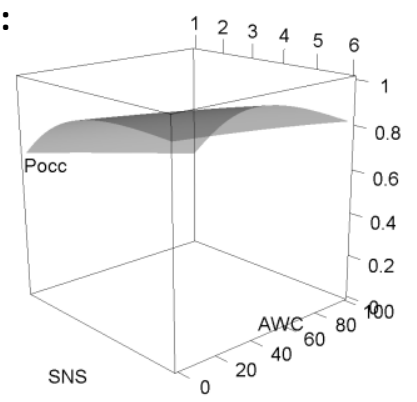

Fsylv
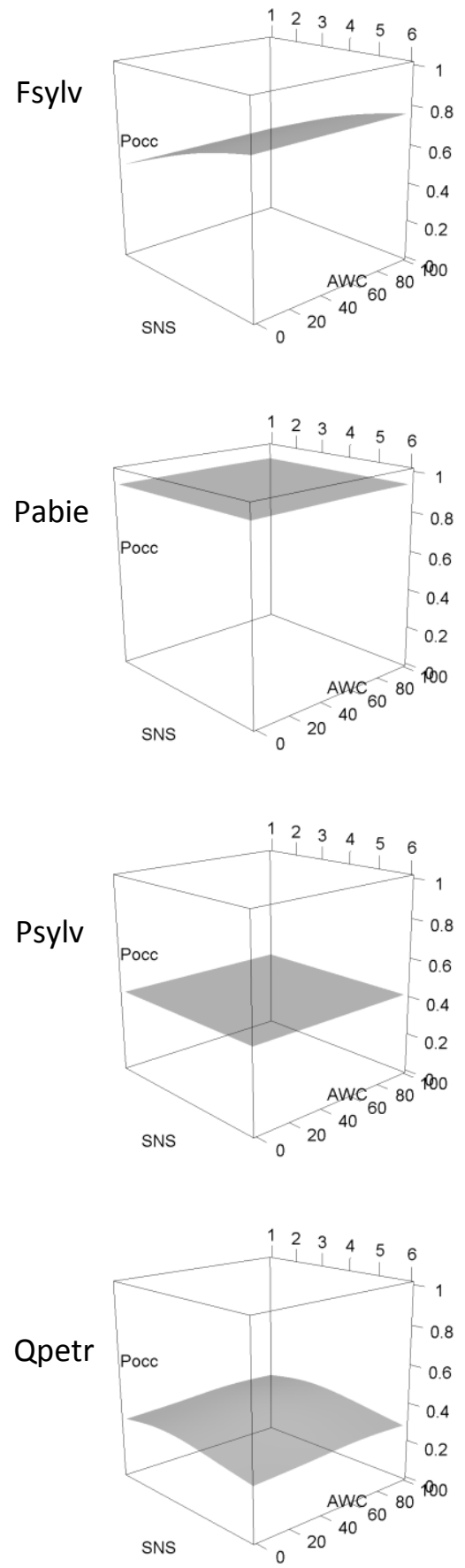

Intermediate (SA2)
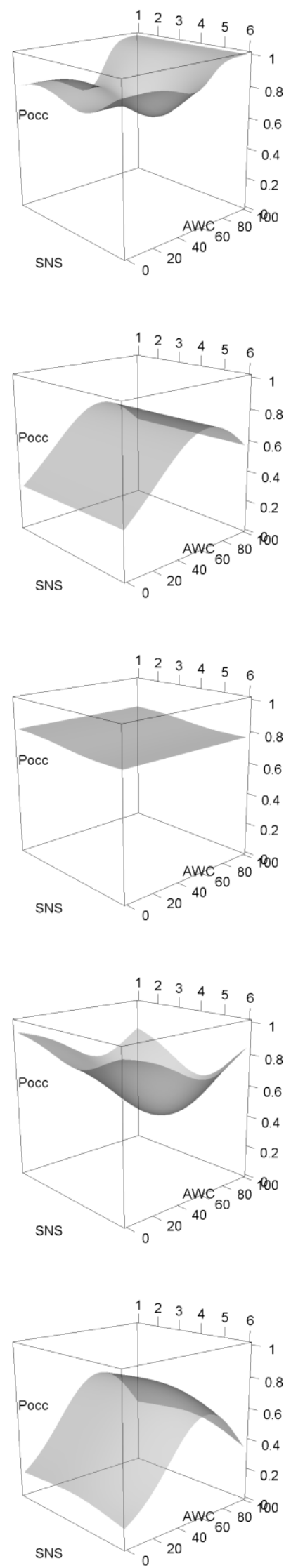

Xeric (SA3)
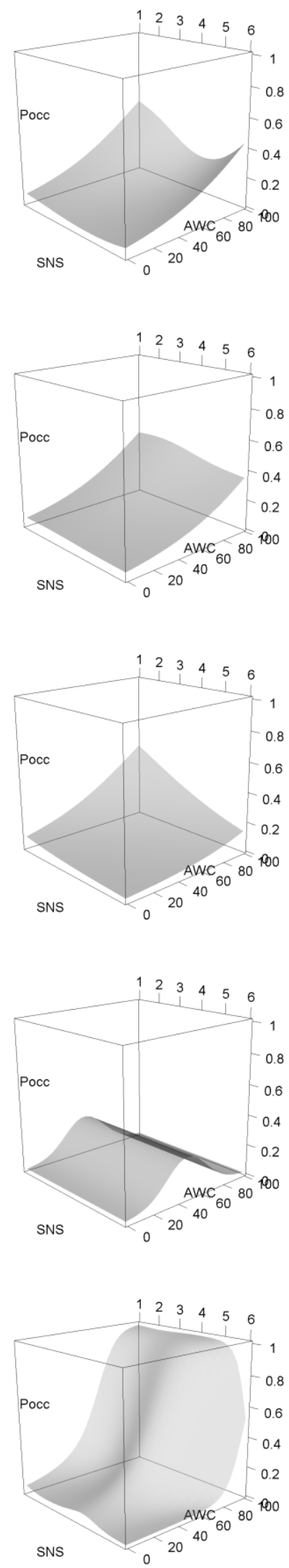


\section{Supplementary material}

775

776

777

778

779

780

781

782

783

784

785

786

787

788

789

790

791

792

793

\section{Species description}

A. alba distribution is restricted to the montane belt, where it commonly grows in mixed stands, mostly with $F$. sylvatica and $P$. abies (element of the Central European mountain flora, Walter 1973) and thrives best on soils with high moisture availability (Wolf 2003; Ellenberg and Leuschner, 2010). The species is very shade tolerant, grows under a wide range of soil $\mathrm{pH}$ conditions from acidic to basic and is moderately droughtsensitive.

F. sylvatica is widely distributed and often dominant in Central and Western Europe (Ellenberg, 1988) and forms extensive stands in Mediterranean mountain ranges. F. sylvatica can grow on soils with widely variable nutrient conditions but favours mesic soils, where root penetration is not constrained by stagnant water (Ellenberg and Leuschner, 2010). Within its range, F. sylvatica tends to dominate other tree species by shading due to rapid crown expansion. However, according to Niinemets and Valladares (2006), F. sylvatica is only moderately tolerant to drought.

P. abies is a boreal tree species that also occurs naturally in the montane and subalpine belts of temperate Europe. It grows mostly in mixtures with other conifers or deciduous trees up to the tree line (Ellenberg and Leuschner, 2010). However, due to its important economic value, the species has been distributed far beyond its natural range, where it was frequently planted in pure stands. Although, $P$. abies is a shade-tolerant tree species that tolerates a wide range of soil types its growth can be limited by soil chemistry (Mellert and Ewald 2014). Its optimum is on mesic soils with balanced nutrient supply (intermediate SNS).

P. sylvestris is widely distributed throughout Eurasia. P. sylvestris is a lightdemanding weak competitor (Niinemets and Valladares, 2006). Although the species tolerates all kinds of site conditions it grows best on fertile soils (intermediate SNS, Ellenberg, 1988; Leibundgut, 1984), where, however, it is outcompeted by $P$. abies or broad-leaved tree species such as F. sylvatica (Ellenberg and Leuschner, 2010). Consequently, the species occurs mainly on poor, sandy soils, rocky outcrops or peat bogs, i.e. at sites where most other tree species are unable to thrive (Mátyás et al., 2004).

Q. petraea is widely distributed in Europe from northern Spain to southern Scandinavia and from Ireland to Ukraine. Q. petraea occupies a very broad range of soil $\mathrm{pH}$ conditions (3.5 to 9) and climate conditions from xeric to hygric (Ducousso and 
808 Bordacs, 2004). It is a light-demanding deciduous tree and more drought tolerant than $F$.

809 sylvatica (Niinemets and Valladares, 2006). In Central Europe, it is preferably found on 810 dry acidic soils (Ellenberg and Leuschner, 2010). 


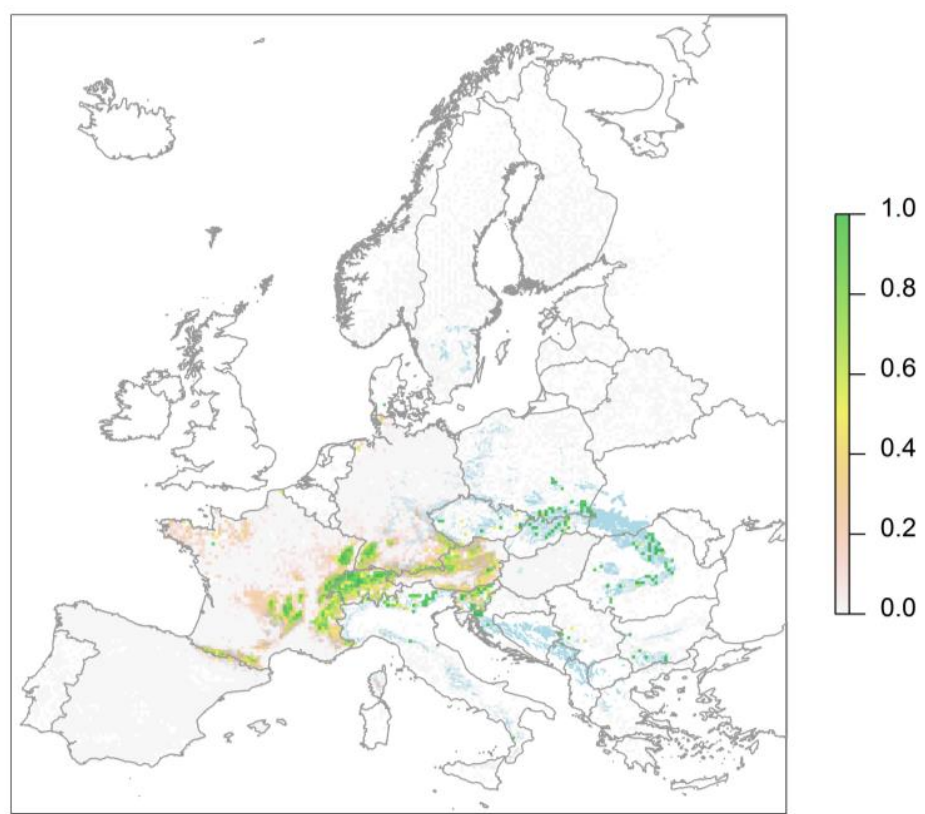

815 Fig. S1 Probability of occurrence of Abies alba observed within a $16 \mathrm{~km}$ raster of Europe 816 (see legend). Distribution area of the species according to Bohn et al. (2003) is displayed 817 in bluish background colors.

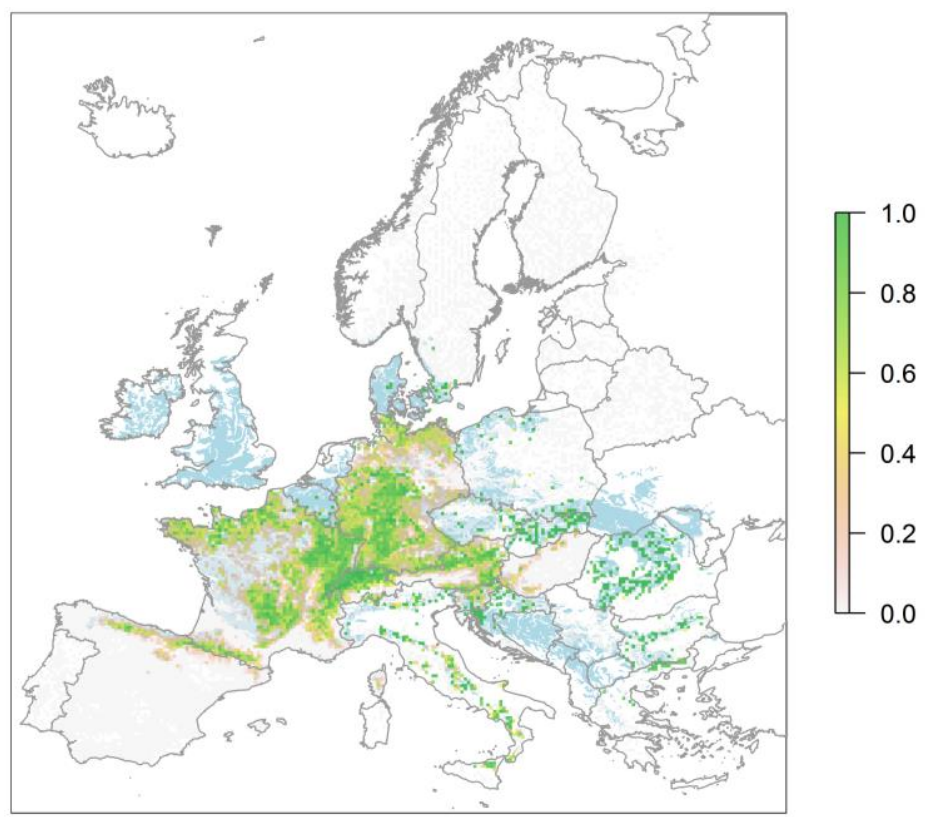


821 Fig. S2 Probability of occurrence of Fagus sylvatica observed within a $16 \mathrm{~km}$ raster of

822 Europe (see legend). Distribution area of the species according to Bohn et al. (2003) is 823 displayed in bluish background colors.

824

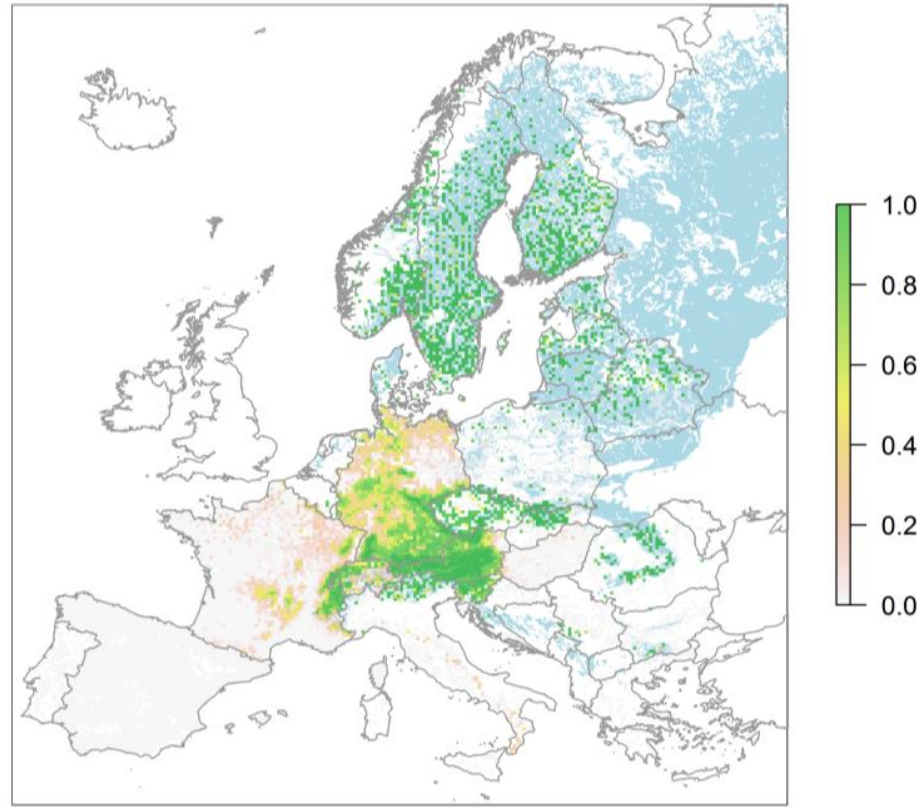

826

Fig. S3 Probability of occurrence of Picea abies observed within a $16 \mathrm{~km}$ raster of Europe

827 (see legend). Distribution area of the species according to Bohn et al. (2003) is displayed 828 in bluish background colors.

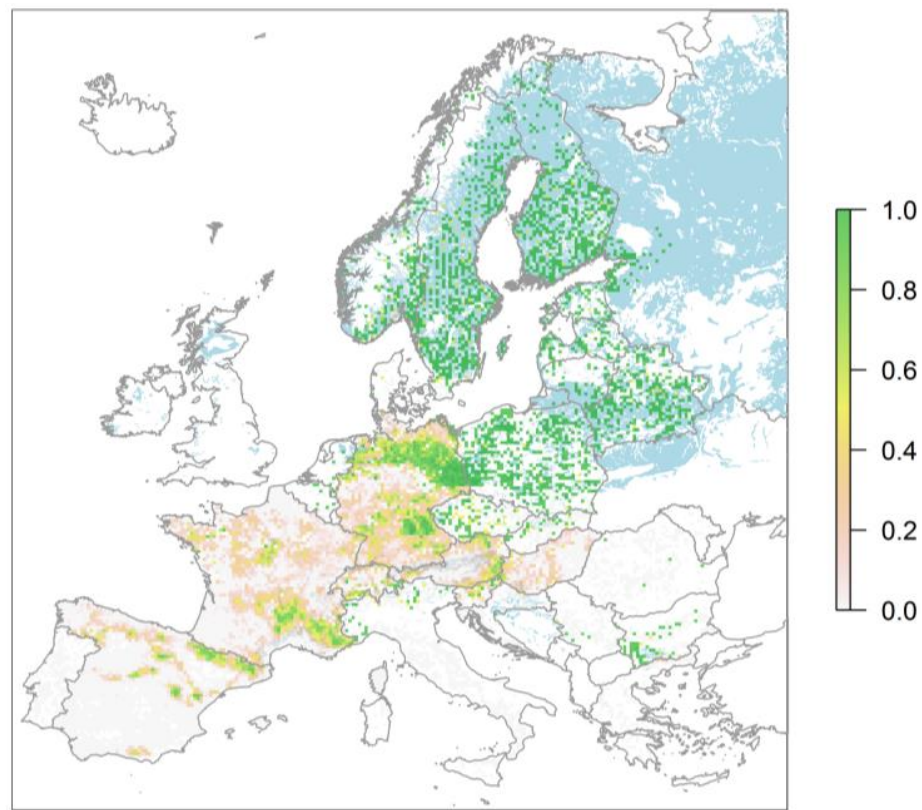


832

833

834

835

836

837

838 Fig. S5 Probability of occurrence of Quercus petraea observed within a $16 \mathrm{~km}$ raster of

Fig. S4 Probability of occurrence of Pinus sy/vestris observed within a $16 \mathrm{~km}$ raster of Europe (see legend). Distribution area of the species according to Bohn et al. (2003) is displayed in bluish background colors.

\section{6}

839 Europe (see legend). Distribution area of the species according to Bohn et al. (2003) is 840 displayed in bluish background colors. 


\section{Soil data}

843 Table S1 Classification of the soil nutrient status (SNS) of terrestrial soil types adopted based on the European Soil Database (ESDB, Panagos 2006) using the soil types from FAO (1974).

845

\section{Order Trophic status}

1 Oligotrotrophic

2 meso-oligotrophic

3 Mesotrophic

4 eutrophic

5 calcareous meso-oligotrophic

\section{Soil types}

Dystric Lithosol, Dystric Ranker, Dystric Regosol, Humic Podzol, Leptic Podzol, Orthic Podzol, Placic Podzol, Dystric Cambisol

Albic Arenosol, Cambic Arenosol, Dystric Cambisol, Dystric Gleysol; Dystric Luvisol, Eutric Lithosol, Ferric Gleysol, Ferric Luvisol, Gelic Regosol, Gleyic Acrisol, Gleyic Cambisol, Haplic Andosol, Haplic Arenosol, Lithosol, Ochric Andosol, Orthic Acrisol, Dystric Lithosol, Orthic Lithosol, Ranker

Albic Luvisol, Dystric Fluvisol, Dystric Planosol, Dystric Podsoluvisol, Eutric Cambisol, Dystric Gleysol, Eutric Gleysol, Eutric Planosol, Eutric Podsoluvisol, Eutric Regosol, Gelic Gleysol, Gleyic Podsoluvisol, Gleyic Podzol, Haplic Cambisol, Humic Gleysol, Luvic Arenosol, Luvic Chernozem, Mollic Planosol, Orthic Greyzem

Albic Cambisol, Eutric Cambisol, Calcaric Fluvisol, Calcaric Gleysol, Calcaric Phaeozem, Chromic Vertisol, Eutric Fluvisol, Gleyic Luvisol, Gleyic Phaeozem, Gleyic Vertisol, Haplic Phaeozem, Humic Chernozem, Luvic Gleysol, Luvic Phaeozem, Mollic Fluvisol, Mollic Gleysol, Ochric Phaeozem, Orthic Luvisol, Pellic Vertisol, Thionic Fluvisol, Thionic Gleysol, Vertic Cambisol, Vertic Luvisol

Calcaric Lithosol, Calcaric Regosol, Calcic Cambisol, Eutric Cambisol, Calcic Chernozem, Calcic Kastanozem, Calcic Luvisol, Chromic Cambisol, Chromic Luvisol, Haplic Kastanozem, Luvic Kastanozem, Cambic Rendzina, Orthic Rendzina, Rendzina

6 calcareous oligotrophic 